\title{
PENGARUH SPRAY HERBAL DARI DAUN KELOR (Moringa oleifera lam) DAN DAUN SIRIH (Piper betle linn) TERHADAP PENYEMBUHAN LUKA SAYAT AYAM KAMPUNG
}

\section{The Effect of Herbal Spray from Moringa Leaves (Moringa oleifera Lam) and Betel Leaves (Piper betle Linn) on Healing of Native Chicken Cuts}

\author{
Muhammad Taufik*, Syarifah Nurul Waqiah, dan Hartina Beddu \\ Jurusan Peternakan, Politeknik Pembangunan Pertanian Gowa \\ Jalan Malino KM.7, Romanglompo, Kecamatan Bontomarannu, Kabupaten Gowa,Sulawesi Selatan \\ *e-mail: taufikpat70@gmail.com
}

Received: 20 September 2021; Accepted: 27 November 2021; Published: 25 Desember 2021

\begin{abstract}
ABSTRAK
Kajian ini bertujuan untuk mengetahui respons peternak terhadap penggunaan spray herbal dari daun kelor dan daun sirih pada penyembuhan luka sayat ayam kampung. Kajian ini dilaksanakan pada bulan April 2021, bertempat di Kelurahan Attangsalo, Kecamatan Ma'rang, Kabupaten Pangkep. Metode kajian ini dilaksanakan dengan menggunakan Rancangan Acak Lengkap (RAL) dengan jumlah ternak 36 ekor ayam kampung dengan 4 perlakuan dan 3 ulangan, masing-masing ulangan terdiri dari 3 ekor ayam. Setiap sampel rancangan percobaan yang digunakan pada kajian ini yaitu P0 (tanpa perlakuan spray herbal daun kelor dan daun sirih), P1 (50 ml spray herbal daun kelor dan $10 \mathrm{ml}$ daun sirih), P2 (50 ml spray herbal daun kelor dan $20 \mathrm{ml}$ daun sirih), P3 (50 ml spray herbal daun kelor dan $30 \mathrm{ml}$ daun sirih). Variable yang diamati adalah pengukuran panjang luka, waktu penyembuhan luka dan waktu pengeringan luka. Hasil kajian ini menunjukkan bahwa spray herbal dari daun kelor $(M$. oleifera $L)$ dan daun sirih $(P$. betle $L)$ dapat mempengaruhi penyembuhan luka sayat pada ayam kampung, dari 4 perlakuan yang paling berpengaruh ada pada P3 dengan konsentrasi $50 \mathrm{ml}$ spray herbal daun kelor dan $30 \mathrm{ml}$ daun sirih.
\end{abstract}

Kata kunci: Daun kelor, daun sirih, luka sayat, spray

\begin{abstract}
This study aims to determine the response of farmers to the use of herbal sprays from moringa leaves and betel leaves in wound healing of native chickens. This study was carried out in April 2021, located in Attangsalo Village, Ma'rang District, Pangkep Regency. This study method was carried out using a completely randomized design (CRD) with a total of 36 native chickens with 4 treatments and 3 replications, each replication consist of 3 chickens. Each experimental design sample used in this study was P0 (without treatment with Moringa leaf herbal spray and betel leaf), P1 (50 ml Moringa leaf herbal spray and $10 \mathrm{ml}$ betel leaf), P2 (50 $\mathrm{ml}$ Moringa leaf herbal spray, and $20 \mathrm{ml}$ Moringa leaf herbal spray). betel leaf), P3 (50 $\mathrm{ml}$ of Moringa leaf herbal spray and $30 \mathrm{ml}$ of betel leaf). The observed variables were the measurement of wound length, wound healing time and wound drying time. The results of this study showed that herbal spray from Moringa leaf $(M$. oleifera $L)$ and betel leaf ( $P$. betle $L)$ could affect wound healing in native chickens, of the 4 treatments the most influential was $P 3$ with a concentration of $50 \mathrm{ml}$ of leaf herbal spray. Moringa and $30 \mathrm{ml}$ of betel leaf.
\end{abstract}

Keywords: Moringa oleifera L., Piper betle L. wound healing, sprays 


\section{PENDAHULUAN}

Luka adalah hilang atau rusaknya sebagian jaringan tubuh. Keadaan ini dapat disebabkan oleh trauma benda tajam atau tumpul, perubahan suhu, zat kimia, ledakan, sengatan listrik atau gigitan hewan. Luka dapat dialami oleh semua orang tidak terkecuali hewan, baik hewan besar maupun kecil. Luka menyebabkan bagian dalam tubuh hewan menjadi terpapar dengan bagian luar tubuh, apabila dibiarkan dan tidak diobati dapat timbul infeksi dan penyembuhan luka akan terhambat. Secara normal luka akan sembuh melalui serangkaian proses yang kompleks dan dinamis (Wombeogo dan Kuubire, 2014). Umumnya penyembuhan luka pada hewan dilakukan dengan pemberian obat kimia berupa salep, spray, serbuk tabur, tablet, pasta dan obat tetes, namun dalam hal ini Penulis menggunakan tanaman kelor dan sirih sebagai bahan utama dalam pengobatan luka pada ternak.

Sejak zaman dahulu tanaman kelor sudah dikenal sebagai tanaman obat tradisional yang banyak khasiatnya. Senyawa pada daun kelor yang berperan dalam penyembuhan luka diantaranya flavonoid, saponin, tannin, antibakteri, antiseptik, antimikroba dan senyawa polifenol. Selain itu, daun kelor juga mengandung asam galat, glikosida quersitin, asam klorogenat yang sangat bermanfaat untuk ramuan herbal (Nurcahyati, 2014).

Tanaman sirih sudah sejak dulu digunakan masyarakat Indonesia sebagai obat tradisional. Tanaman sirih merupakan salah satu tanaman yang mempunyai daya antibakteri dimana kemampuan tersebut karena adanya berbagai zat yang terkandung didalamnya seperti flafonoid, saponin, dan tannin. Khasiat antibakteri daun sirih telah dibuktikan dari penelitian (Kursia et al, 2016).

Ayam kampung merupakan ayam lokal Indonesia yang biasa juga disebut dengan ayam buras (bukan ras). Penyebaran ayam buras mudah dijumpai di Indonesia dengan jenis dan penampilan ayam kampung yang beragam. Ayam kampung juga memiliki potensi yang baik untuk dikembangkan terutama dalam meningkatkan gizi dan pendapatan masyarakat (Subekti dan Arlina, 2011) namun, ayam kampung memiliki sifat kanibalisme yang secara alami suka mematuk dan bertarung yang menyebabkan ayam kampung terluka. Hal inilah yang kurang diperhatikan oleh peternak dimana peternak tidak melakukan penanganan pada luka ternak hingga dibiarkan infeksi dan dapat berakibat kematian.

Kelurahan Attangsalo, Kecamatan Ma'rang, Kabupaten Pangkep merupakan daerah yang masyarakatnya banyak memelihara ayam kampung, namun kurangnya perhatian peternak terhadap luka pada ayam kampung begitu pula tanaman kelor (M. oleifera $L)$ dan tanaman sirih $(P$. betle $L)$ banyak disekitar lingkungan masyarakat, akan tetapi masyarakat kurang memanfatkan tanaman kelor $(M$. oleifera $L)$ dan tanaman sirih $(P$. betle $L)$ oleh sebab itu, hasil kajian diharapkan dapat memberi informasi ilmiah untuk menjadikan tanaman kelor $(M$. oleifera $L)$ dan tanaman sirih $(P$. betle $L)$ sebagai salah satu alternatif pengobatan luka sayat pada ayam kampung serta dapat meningkatkan pengetahuan dan sikap peternak tentang penggunaan spray herbal dari daun kelor dan daun sirih pada penyembuhan luka sayat ayam kampung.

\section{MATERI DAN METODE}

\section{Tempat dan Waktu}

Kajian ini akan dilaksanakan di Kelurahan Attangsalo, Kecamatan Ma'rang, Kabupaten Pangkep, Provinsi Sulawesi Selatan pada bulan April hingga Juni 2021.

\section{Alat dan Bahan}

Alat yang digunakan dalam kajian ini yaitu, timbangan, toples, pengaduk, saringan, blender, botol spray, gelas ukur, kandang, penggaris, alat tulis, dan kamera. Bahan yang digunakan dalam kajian yaitu daun kelor, daun sirih, alkohol 70\%, ayam kampung, sarung tangan, kapas, spidol, kertas, pulpen, folder, LPM, kuesioner, dan kertas koran.

\section{Metode Pelaksanaan}

Kajian ini menggunakan Rancangan Acak Lengkap (RAL) yang terdiri dari 4 perlakuan dan 3 ulangan sehingga terdapat 12 kali percobaan. Kelompok perlakuan dibagi menjadi 4 kelompok yaitu:

$\mathrm{P} 0=$ Tanpa perlakuan (Kontrol)

P1 = Daun Kelor $50 \mathrm{ml}$ dan Daun Sirih $10 \mathrm{ml}$

P2 = Daun Kelor $50 \mathrm{ml}$ dan Daun Sirih $20 \mathrm{ml}$

P3 = Daun Kelor $50 \mathrm{ml}$ dan Daun Sirih $30 \mathrm{ml}$ 


\section{Pelaksanaan Kajian}

a) Pembuatan Spray Herbal dari Daun Kelor (M. oleifera $L)$ dan Daun Sirih (P. betle $L)$

Daun kelor dan daun sirih dicuci dengan air bersih dan ditiriskan, Setelah ditiriskan daun kelor dan daun sirih kemudian dikeringkan dengan menggunakan sinar matahari hingga setengah kering, kemudian daun kelor dan daun sirih diblender hingga menjadi serbuk.

Pembuatan spray ini menggunakan cara sonikasi, yaitu dengan cara memasukkan daun kelor sebanyak 25 gram dan daun sirih sebanyak 25 gram kedalam toples kecil yang berbeda kemudian, tambahkan etanol $70 \%$ sebanyak 50 $\mathrm{ml}$ sebagai pelarut dan diaduk hingga larut. Selanjutnya disaring sehingga didapatkan filtrat. Filtrat yang diperoleh ditampung dalam toples, sehingga diperoleh ekstrak dari daun kelor dan daun sirih. Selanjutnya ekstrak dimasukkan kedalam botol spray yang disesuaikan dengan takarannya dan siap untuk diaplikasikan pada ternak ayam kampung.

\section{b) Perlakuan Pada Kelompok Hewan Uji}

Ayam kampung yang digunakan yaitu umur 3 bulan. Kemudian di cukur bulunya pada bagian tubuh ternak yang akan diinduksi, sebelum diinduksi oleskan alkohol $70 \%$ menggunakan kapas agar terhindar dari bakteri ataupun kotoran yang menempel, kemudian diinduksi. Luka yang terjadi di semprotkan spray herbal hingga merata pada bagian luka ternak ayam kampung dan dilakukan sebanyak 3 kali sehari kemudian diberi perlakuan P0, P1, P2 dan P3 pada bagian tubuh yang luka.

\section{Parameter Pengamatan}

a) Perhitungan Ukuran Panjang Luka

Penyembuhan luka dinilai dengan dilakukan pengukuran setiap hari dengan batas waktu 14 hari untuk melihat perbedaannya. Selama penelitian digunakan teknik observasi eksperimen, dimana 4 perlakuan pada masingmasing ayam kampung dilakukan pengamatan pada hari ke 1 dan 14 untuk melihat penyembuhan luka secara makroskopis (Suratman et al., 1996).

b) Perhitungan Waktu Penyembuhan Luka

Metode untuk menilai waktu penyembuhan luka adalah waktu penyembuhan dihitung dalam hari berdasarkan pada indikator kesembuhan. Indikator kesembuhan adalah diameter luka yang diukur dan persentase penyembuhan. Setelah waktu penyembuhan luka didapat kemudian dilakukan perhitungan persentase penyembuhan luka. Dapat dihitung dengan rumus sebagai berikut :

$$
\mathrm{P} \%=\frac{d o-d x}{d o} x 100
$$

Keterangan:

$$
\begin{aligned}
& \mathrm{P} \%=\text { Persentase Penyembuhan } \\
& \text { do }=\text { Panjang luka awal } \\
& \mathrm{dx}=\text { panjang luka akhir }
\end{aligned}
$$

c) Pengeringan Luka

Metode untuk menilai pengeringan luka pada ternak adalah melihat berdasarkan pada kondisi tubuh ternak yang luka tidak lagi mengalami pendarahan dan terjadinya pembentukan jaringan baru dan tepi luka menyusut dan menutup namun bekas luka pada ternak akan berbeda dengan kulit normal karena kulit tersusun dari dua protein yang memberi kekuatan kulit dan elastin yang memberi kelenturan kulit. Kulit baru yang terbentuk pada bekas luka ini kuat, tetapi kurang lentur dibandingkan kulit disektarnya.

\section{Analisis Data}

Analisis data yang digunakan dalam kajian ini yaitu data yang diperoleh diolah dengan sidik ragam sesuai dengan Rancangan Acak Lengkap (RAL) dengan bantuan microsof excel dan software SPSS. Adapun model matimatikanya (Gasperz,1991) adalah:

Keterangan :

$$
\mathrm{Yij}=\mu+a i+\varepsilon i j
$$

Yij = Nilai pengamatan pada perlakuan ke-i dan ulangan ke-j

$\mu=$ Nilai rata-rata umum

$a i=$ Pengaruh perlakuan ke-i

$\varepsilon i j=$ Pengaruh galat perlakuan ke-i dan ulangan ke-j

$i=$ Perlakuan $1,2,3,4$

$j=$ Ulangan $1,2,3$

\section{HASIL DAN PEMBAHASAN}

Data pengamatan dan hasil analisis diuji dengan metode uji statistic One Way Anova dengan Statistical Produk and Service Solution (SPSS), dan data yang signifikan selanjutnya 
diteruskan menggunakan uji Duncan. Uraian hasil dari parameter yang diamati dapat dilihat pada Tabel 1.

Hasil kajian yang diperoleh berupa penurunan ukuran panjang luka, waktu penyembuhan luka dan waktu pengeringan luka pada pemberian spray herbal dari daun kelor $(M$. oleifera $L$ ) dan daun sirih ( $P$. betle $L$ ). Pengujian spray herbal ini menggunakan 4 kelompok perlakuan yang memiliki konsentrasi ekstrak yang berbeda dan dilakukan 3 kali ulangan. Pengujian 4 kelompok perlakuan yaitu (P0, P1, $\mathrm{P} 2, \mathrm{P} 3) . \mathrm{P} 0=$ tanpa perlakuan (kontrol negative), $\mathrm{P} 1$ = daun kelor $50 \mathrm{ml}$ daun daun sirih $10 \mathrm{ml}, \mathrm{P} 2$ = daun kelor $50 \mathrm{ml}$ dan daun sirih $20 \mathrm{ml}$, dan P3 = daun kelor $50 \mathrm{ml}$ dan daun sirih $30 \mathrm{ml}$

Tabel 1. Ukuran panjang luka, waktu penyembuhan luka dan waktu pengeringan luka pada pemberian spray herbal dari daun kelor $(M$. oleifera $L)$ dan daun sirih $(P$. betle $L)$

\begin{tabular}{clcccc}
\hline No & Parameter & P0 & P1 & P2 & P3 \\
\hline 1 & Ukuran panjang luka & $1,84^{\mathrm{c}}$ & $1,66^{\mathrm{b}}$ & $1,61^{\mathrm{b}}$ & $1,18^{\mathrm{a}}$ \\
2 & Waktu penyembuhan luka & $13,66^{\mathrm{b}}$ & $12,66^{\mathrm{b}}$ & $11,66^{\mathrm{b}}$ & $8,33^{\mathrm{a}}$ \\
3 & Waktu pengeringan luka & $10,33^{\mathrm{c}}$ & $8,33^{\mathrm{b}}$ & $8,33^{\mathrm{b}}$ & $4,66^{\mathrm{a}}$ \\
\hline
\end{tabular}

${ }^{\mathrm{ab}}$ superskrip berbeda pada baris yang sama menunjukkan perbedaaan nyata $(\mathrm{P}<0.05)$

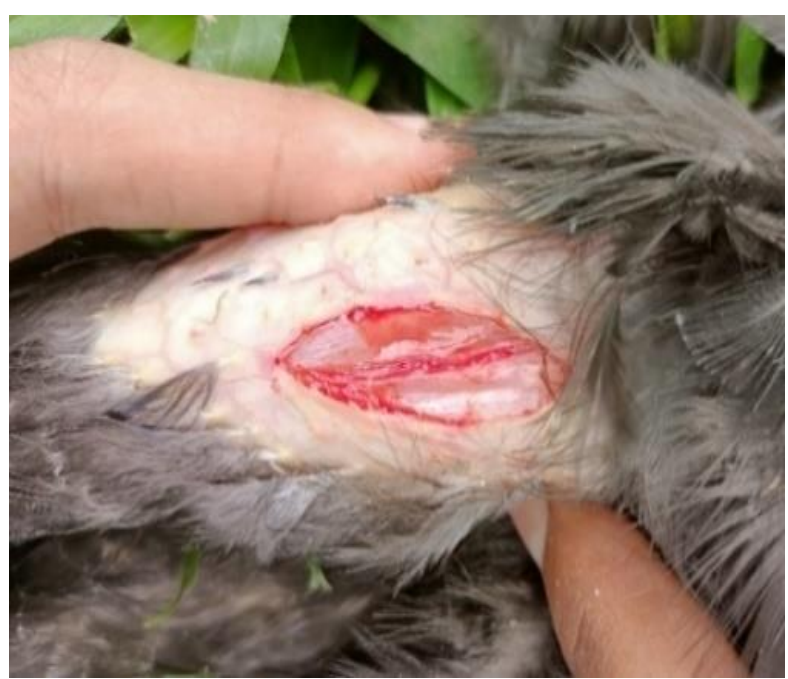

(A)

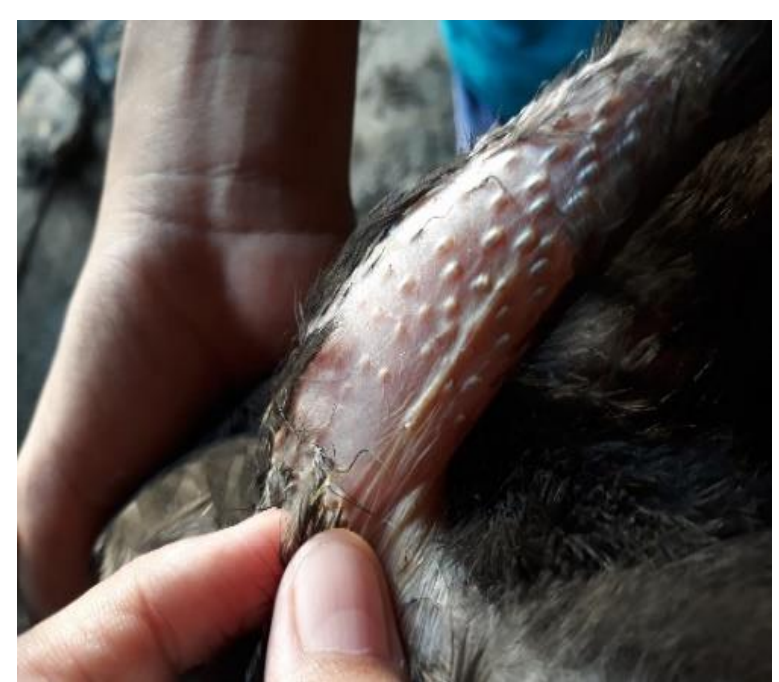

(B)

Gambar 1. Gambar (A) menunjukkan hasil kajian dan (B) sesudah pengobatan menggunakan spray herbal dari daun kelor (M. oleifera $L)$ dan daun sirih (P. betle $L)$

Berdasarkan data diatas menunjukkan bahwa hasil analisis menggunakan daun kelor dan daun sirih sebagai obat alternative penyembuh luka sayat pada ayam kampung memberikan pengaruh nyata terhadap waktu penurunan ukuran panjang luka sayat. Terlihat pada uji lanjut Duncan bahwa P3 berbeda nyata dengan $\mathrm{P} 0, \mathrm{P} 1$, dan $\mathrm{P} 2$, Adapun grafik penurunan ukuran panjang luka dapat dilihat pada gambar 2 .

Gambar 2. menunjukkan penyembuhan luka sayat pada ayam kampung mengalami percepatan pada kelompok perlakuan P3 dengan konsentrasi ekstrak daun kelor $50 \mathrm{ml}$ dan daun sirih $30 \mathrm{ml}$ yang ditunjukkan pada garis berwarna ungu, garis berwarna hijau merupakan kelompok perlakuan P2 dengan konsentrasi ekstrak daun kelor $50 \mathrm{ml}$ dan daun sirih $20 \mathrm{ml}$, garis merah merupakan kelompok perlakuan P1 dengan konsentrasi ekstrak daun kelor $50 \mathrm{ml}$ dan daun sirih $10 \mathrm{ml}$ dan garis biru merupakan P0 (tanpa perlakuan).

Data pengamatan waktu penyembuhan luka diatas menunjukkan bahwa rata-rata perlakuan menunjukkan waktu penyembuhan luka pada perlakuan (P0) tanpa diobati sembuh pada hari ke 14,(P1) Luka diberi spray ekstrak 50 $\mathrm{ml}$ daun kelor dan $10 \mathrm{ml}$ ekstrak daun sirih sembuh pada rata-rata hari ke 13, (P2) Luka 
diberi spray ekstrak $50 \mathrm{ml}$ daun kelor dan $20 \mathrm{ml}$ ekstrak daun sirih sembuh pada rata-rata hari ke 12, (P3) Luka diberi spray ekstrak $50 \mathrm{ml}$ daun kelor dan $30 \mathrm{ml}$ ekstrak daun sirih sembuh pada rata-rata hari ke 8 . Berdasarkan hasil analisis penggunaan spray dari daun kelor dan daun sirih sebagai obat alternative luka sayat pada ayam kampung memberikan pengaruh nyata terhadap waktu penyembuhan luka. Dengan uji lanjut Duncan terlihat bahwa P3 berbeda nyata dengan P0, P1 dan P2.

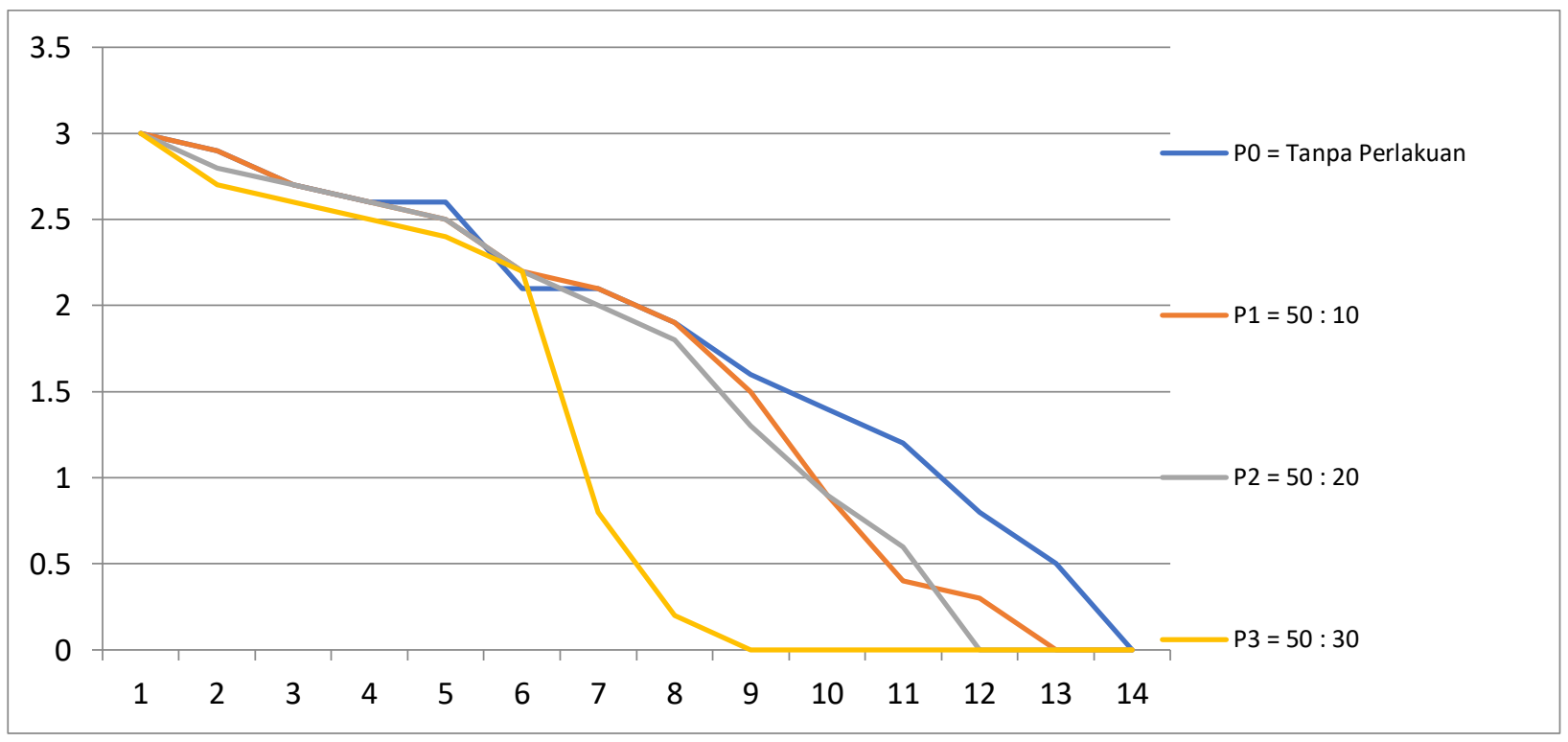

Gambar 2. Grafik penurunan panjang luka

Data pengamatan waktu pengeringan luka diatas menunjukkan bahwa rata-rata perlakuan menunjukkan waktu pengeringan luka pada perlakuan (P0) tanpa diobati mengering pada hari ke 10, (P1) Luka diberi spray ekstrak 50 $\mathrm{ml}$ daun kelor dan $10 \mathrm{ml}$ ekstrak daun sirih mengering pada rata-rata hari ke $8,(\mathrm{P} 2)$ Luka diberi spray ekstrak $50 \mathrm{ml}$ daun kelor dan $20 \mathrm{ml}$ ekstrak daun sirih mengering pada rata-rata hari ke 8, (P3) Luka diberi spray ekstrak $50 \mathrm{ml}$ daun kelor dan $30 \mathrm{ml}$ ekstrak daun sirih mengering pada rata-rata hari ke 5. Berdasarkan hasil analisis penggunaan spray dari ekstrak daun kelor dan daun sirih sebagai obat alternative luka sayat pada ayam kampung memberikan pengaruh nyata terhadap waktu pengeringan luka. Dengan uji lanjut Duncan terlihat bahwa P3 berbeda nyata dengan P0, P1 dan P2.

Berdasarkan hasil uji yang telah dilakukan dapat dilihat dari empat kelompok perlakuan dengan tiga kali ulangan, penyembuhan luka sayat pada ayam kampung paling cepat pada pemberian spray daun kelor 50 $\mathrm{ml}$ dan daun sirih $30 \mathrm{ml}$, sedangkan penyembuhan luka paling lama pada kontrol negatif (tanpa perlakuan).
Penyembuhan luka sayat pada ayam kampung dengan menggunakan spray daun kelor dan daun sirih disetiap kelompok perlakuan relatif berbeda, hal ini disebabkan karena pemberian ekstrak daun kelor dan daun sirih yang berbeda-beda disetiap perlakuan, dimana semakin tinngi pemberian konsentrasi ekstrak daunnya maka semakin cepat proses penyembuhan luka. Hal tersebut juga dikarenakan daun kelor dan daun sirih mengandung zat aktif seperti tanin, saponin, flavonoid, dan steroid yang mampu mempercepat penyembuhan luka (Benjamin, 1987).

Tanin berfungsi sebagai astringen yang dapat menyebabkan penciutan pori-pori kulit, menghentikan eksudat dan pendarahan ringan (Anief, 1997). Tanin juga mempunyai daya antibakteri dengan cara mempresipitasi protein, karena diduga tanin mempunyai efek yang sama dengan senyawa fenolik (Masduki, 1996). Saponin memiliki kemampuan sebagai pembersih dan antiseptik yang berfungsi membunuh kuman atau mencegah pertumbuhan mikroorganisme yang biasa timbul pada luka sehingga luka tidak mengalami infeksi yang berat (Robinson, 1995). 
Flavonoid berfungsi sebagai antibakteri dengan cara membentuk senyawa kompleks terhadap protein extraseluler yang mengganggu integritas membran sel bakteri, flavonoid merupakan senyawa feno sementara senyawa fenol dapat berifat koogulator protein (Dwidjoseputro, 1994). Selain itu,flavonoid memiliki efek antiinflamasi dimana berfungsi sebagai anti radang dan mampu mencegah kekakuan dan nyeri. flavonoid juga berfungsi sebagai antioksidan sehingga mampu menghambat zat yang bersifat racun (Anggraini 2008).

Steroid sebagai anti radang yang mampu mencegah kekakuan dan nyeri. Walaupun senyawa steroid dan flavonoid ini sama-sama bersifat sebagai antiinflamasi namun flavonoid lebih mempercepat penyembuhan luka dibandingkan dengan steroid. Hal ini disebabkan karena kemampuan flavonoid mencegah oksidasi dan menghambat zat yang bersifat racun yang bisa timbul pada luka (Simanjuntak, 2008).

\section{KESIMPULAN}

Pemberian Spray herbal ekstrak daun kelor $50 \mathrm{ml}$ dan daun sirih $30 \mathrm{ml}$ efektif digunakan sebagai obat alternative untuk penyembuhan luka sayat pada ayam kampung karena proses penyembuhannya lebih baik dan cepat dibandingkan (P1) Spray herbal ekstrak daun kelor $50 \mathrm{ml}$ dan daun sirih $10 \mathrm{ml}$, (P2) Spray herbal ekstrak daun kelor $50 \mathrm{ml}$ dan daun sirih 20 $\mathrm{ml}$ dan kontrol negative $\mathrm{P} 0$ yaitu tanpa perlakuan.

\section{SARAN}

Perlu dilakukan penelitian lebih lanjut terkait lama penyimpanan dan metode pengemasan spray herbal dari daun kelor dan daun sirih yang lebih baik dan efektif serta pengobatan pada jenis ternak lainnya.

\section{DAFTAR PUSTAKA}

Anggraini, W. 2008. Efek Antiinflamasi Ekstrak Etanol Daun Jambu Biji (Psidium guajava Linn.) pada Tikus Putih Jantan Galur Wistar. Fakultas Farmasi, UMS : Surakarta [Skripsi].
Arief, M. 1997. Formulasi Obat Topikal Dengan Dasar Penyakit Kulit. Gajah Mada University Press : Yogyakarta.

Benjamin, V.T, 1987., Phytochemical and Antibacterial Studies on The Essential Oil of Euphatorium Odoratum, Available online at http://www.Pharmaceutical Biology.htm.

Dwidjoseputro D. 1994. Dasar-Dasar Mikrobiologi. Djambatan, Jakarta.

Ginting, E. 1991. Metode Kuliah Kerja Lapangan. Universitas Brawijaya, Malang.

Kursia, S. et al. 2016. Uji Aktivitas Antibakteri Ekstrak Etilasetat Daun Sirih Hijau (Piper Betle L.) terhadap Bakteri Staphylococcus epidermidis Antibacterial Activity Test of Ethylacetate Extract of Green Betel Leaf (Piper Betle L.) towards Staphylococcus epidermidis Bact, IJPST, 3.

Mardiana, Lina. 2012. Daun Ajaib Tumpas Penyakit. Jakarta : Penebar Swadaya.

Mardikanto, T., 2014. CSR (Corporate Sosial Responsibility) Tanggung Jawab Sosial. Cetakan-1, Bandung, Alfabeta.

Masduki I. 1996. Efek Antibakteri Ekstrak Biji Pinang (Areca catechu) terhadap S. aureus dan E. coli. Cermin Dunia Kedokteran $109: 2$.

Melo, N. V., Vargas, T. Quirino and C. M. C. Calvo. 2013. Moringa oleifera L. An underutilized tree with macronutrients for human health. Emir. J. Food Agric, 25 (10): 785-789.

Miladiyah, I., Prabowo, B.R., 2012, Ethanolic extract of Anredera cordifolia(Ten.) Steenisleaves improved wound healing in guinea pigs, Universa Medicina, 31(1):411.

Nurcahyati, Erna. 2014. Khasiat Dahsyat Daun Kelor. Jakarta : Jendela Sehat.

Robinson, T, 1995., Kandungan Organik Tumbuhan Tinggi, Edisi VI, ITB, Bandung.

Simanjuntak, M.R. 2008. Ekstraksi dan Fraksinasi Komponen Ekstrak Daun Tumbuhan Senduduk (melastoma malabathricum. L) Serta Pengujian Efek 
Sediaan Krim terhadap Penyembuhan Luka Bakar. Skripsi. Universitas Sumatera Utara. Medan. $85 \mathrm{hlm}$.

Subekti, K. dan F. Arlina. 2011. Karakteristik genetic eksternal ayam kampung di Kecamatan Sungai Pagu Kabupaten
Solok Selatan. Jurnal Ilmiah Ilmu-Ilmu Peternakan 15(2):74-86.

Wombeogo, M. and Kuubire, C.B. 2014, Trauma and Emergency Health Care Manual, Author House TM UK Ltd: Bloomington. 